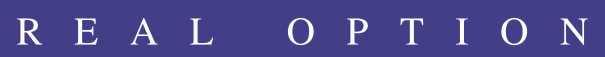
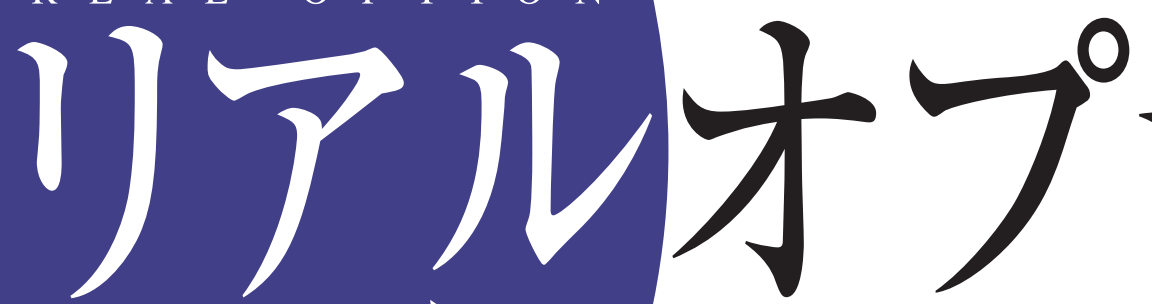

日本リアルオプション学会機関誌
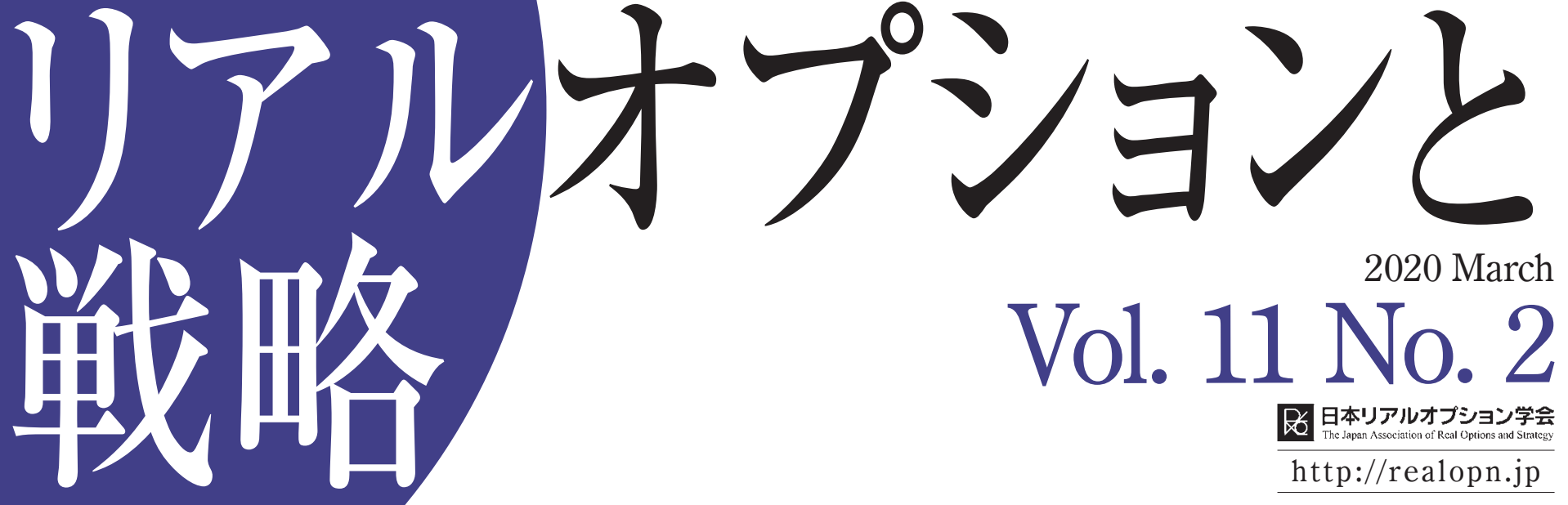

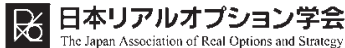

http://realopn.jp

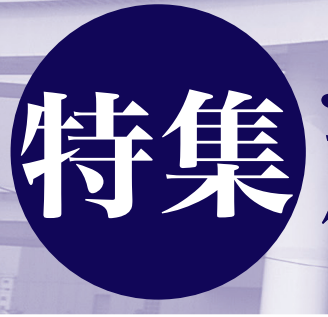

JAROS 2019

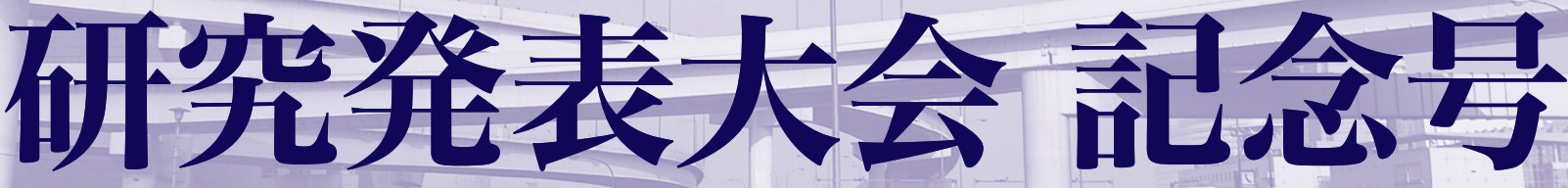

巻頭言

コロナ禍で「ESGプット」は存在したのか？[湯山 智教]

1

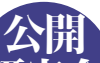

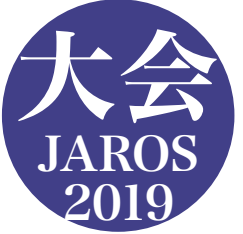

講演要旨

ストック型インターネットメディアの特徵 [加藤㕕晃 $]$

一ストック型コンテンツ開発と収益化についてー

インバウンドとニューツーリズム - 新しい旅行スタイルを求める訪日外国人たち－ [安田 亘宏］８

産業用ドローン市場の展望 一自律制御技術による業務効率化・無人化一 [早川 研介] — 13

終末期ケアのイノベーションと普及 - 在宅ホスピスの可能性－ [高橋 正 $] 20$

これからの都市防災 〜不透明な未来に向けて〜 [廣井 悠 $]$

エネルギー・リスクマネジメントと海上輸送 [鳥海 重喜]

人口減少時代のビジネスモデルと事業ポートフォリオ戦略 [長欲川 直和]

AI vs. 人間という二項対立への疑問 〜翻訳会社の立場から〜 [宮 俊一郎 $]$

Pythonパッケージを用いた数理最適化の実践 [小林 和博]

JAROS2019大会ルポ [佐藤 公俊・伊藤 晴祥 $]$

リスク鋭感的価值尺度 (RSVM) の拡張とその応用 [宮原 孝夫]

後藤 允 著『投資戦略の数理モデル 〜リアルオプションの基礎と理論〜』[高森 寛] 


\section{第11巻 第2号}

目次

\section{巻頭言}

コロナ禍で「ESGプット」は存在したのか?

湯山智教 1

\section{公開研究会 講演要旨}

ストック型インターネットメデイアの特徴

加藤 広晃 2

一 ストック型コンテンツ開発と収益化について —

インバウンドとニューツーリズム — 新しい旅行スタイルを求める訪日外国人たち—……安田 亘宏 8

産業用ドローン市場の展望 一自律制御技術による業務効率化·無人化 一 早川研介 13

終末期ケアのイノベーションと普及 — 在宅ホスピスの可能性 — 高橋 正 20

\section{特集：2019研究発表大会}

\section{〈基調講演〉}

これからの都市防災 〜不透明な未来に向けて〜 廣井悠 24

エネルギー・リスクマネジメントと海上輸送 鳥海 重喜 31

人口減少時代のビジネスモデルと事業ポートフオリオ戦略 長谷川 直和 36

AI vs. 人間という二項対立への疑問 〜翻訳会社の立場から〜 二宮 俊一郎 41

〈チュートリアルセッション〉

Pythonパッケージを用いた数理最適化の実践 小林 和博 46

〈大会ルポ〉

JAROS2019大会ルポ 佐藤 公俊·伊藤 晴祥 52

\section{研究メモ}

リスク鋭感的価值尺度 $(R S V M)$ の拡張とその応用 宮原 孝夫 55

\section{書評}

後藤 允 著『投資戦略の数理モデル 〜リアルオプションの基礎と理論〜』 高森 寛 59 
日本リアルオプション学会 機関誌

リアルオプションと戦略 第11巻 第2号

2020年3月31日 発行

発行所 日本リアルオプション学会

THE JAPAN ASSOCIATION OF REAL OPTIONS AND STRATEGY

\section{事務業務担当：}

T104-0033

東京都中央区新川2-22-4 新共立ビル $2 \mathrm{~F}$

電話： 03-3551-9893 FAX：03-3553-2047 


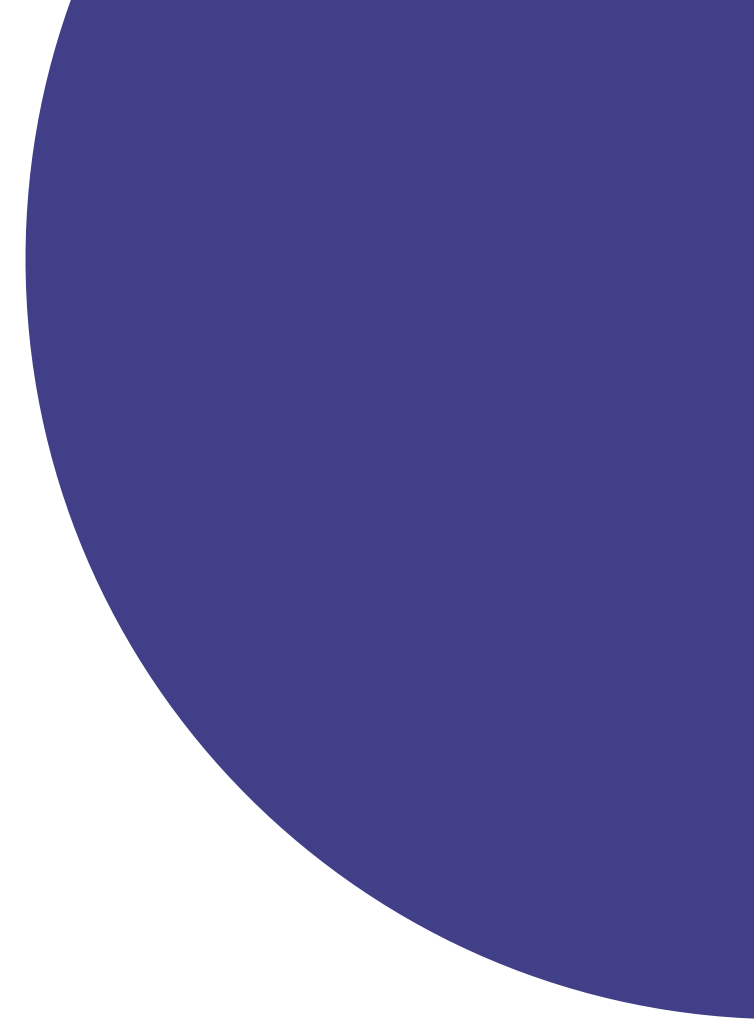

民。 日本リアルフプション学会

http://realopn.jp 